\title{
Soil chemical attributes in coffee growing with different agronomic techniques
}

\author{
Giovani Belutti Voltolini' (iD), Larissa Cocato da Silva1 (iD), Ademilson de Oliveira Alecrim ${ }^{1}$ (D), Dalyse Toledo Castanheira ${ }^{2}$ (D), \\ Laís Sousa Resende ${ }^{1}$ (D), Tiago Teruel Rezende ${ }^{3}$ (D), Rubens José Guimarães ${ }^{1}$ (D)
}

\author{
${ }^{1}$ Universidade Federal de Lavras/UFLA, Departamento de Agricultura/DAG, Lavras, MG, Brasil \\ ${ }^{2}$ Universidade Federal de Viçosa/UFV, Departamento de Fitotecnia/DFT, Viçosa, MG, Brasil \\ ${ }^{3}$ Universidade José do Rosário Vellano/UNIFENAS, Alfenas, MG, Brasil \\ Contact authors: giovanibelutti77@hotmail.com, cocatolarissa@gmail.com, ademilsonagronomia@gmail.com, dalysecastanheira@hotmail.com, \\ sialresende@gmail.com, tiago.rezende@unifenas.br, rubensjg@dag.ufla.br \\ Received in December 5, 2019 and approved in July 16, 2020
}

\section{ABSTRACT}

The objective was to evaluate the chemical attributes in a coffee growing area, according to different agronomic techniques used and their associations. The experiment was conducted in the field, from January 2016 to October 2018. Coffee was planted in January 2016, with Mundo Novo IAC 379-19 coffee seedlings, with a spacing of $3.6 \mathrm{~m}$ between rows and $0.75 \mathrm{~m}$ between plants in the planting row. The factors under study were arranged in a $3 \times 2 \times 5$ factorial scheme, making a total of 30 treatments. In the plots, three soil managements were randomized (soil cover with polyethylene film, soil cover with brachiaria-grass and conventional management of spontaneous vegetation). In the subplots, two types of fertilizers (conventional and increased-efficiency fertilizer). In the sub-subplots, four soil conditioners (coffee husk, phosphogypsum, water retention polymer, organic compost), and the control without conditioner. Aimed to evaluate soil chemical attributes in coffee growing with different agronomic techniques through the evaluation of: soil $\mathrm{pH}$, phosphorus $(\mathrm{P})$, potassium $(\mathrm{K})$, calcium $(\mathrm{Ca})$, magnesium $(\mathrm{Mg})$, aluminum saturation $(\mathrm{m})$ and base saturation $(\mathrm{V} \%)$. The use of fertilizers combined with the application of organic compost or coffee husk, provide increased soil $\mathrm{pH}$, as well as the use of ecological management of brachiaria-grass. The use of organic compost as a soil conditioner increases phosphorus availability in the soil. Coffee husk, as a soil conditioner, is an efficient potassium source for the coffee crop. The use of organic compost and phosphogypsum increases the calcium and magnesium contents in the soil. The use of organic compost and coffee husk was efficient in increasing the base saturation grown with coffee. The use of organic compost, coffee husk and phosphogypsum reduced aluminum saturation in the soil. Treatments associated with the use of organic compost improve calcium, phosphorus and magnesium levels, increase pH and base saturation, besides decreasing aluminum saturation.

Key words: Coffea arabica; soil managements; fertilizers; soil conditioners.

\section{INTRODUCTION}

The growing demand for quality and quantity of coffees in the world requires improvements in crop systems to be sought. The importance of coffee in the world is highlighted, with great impact on the economy of producing countries and, consequently, on the lives of people involved in this production process International Coffee Organization (ICO, 2017).

Brazil is the world's largest coffee producer and exporter, accounting for about $30 \%$ of all coffee trade, and is the second largest consumer market, with the prospect of soon becoming the largest consumer, surpassing the United States of America. This is a prominent position in the world, as this important agricultural commodity is the second most consumed beverage in the world, considering water in the first place (ICO, 2017).

There are several factors that affect the yield and quality of coffee fruits such as: nutrition, plant water relations, soil characteristics and many others (Oliveira et al., 2013). Thus, the use of vegetable or artificial cover in coffee areas has shown a positive effect on both soil and plant characteristics (Rocha et al., 2014).
With the use of brachiaria grass, the soil cover has been researched aiming at understanding the characteristics that comprise this system and the proper cultivation with the grass between coffee rows (Ragassi; Pedrosa; Favarin, 2013). Another way to cover the soil is by using polyethylene film, that appears as an alternative for coffee cultivation, since its effectiveness has been observed in other crops, such as horticulture (Yuri et al., 2012).

Other technologies with potential for improvement in the coffee production system are the use of increased-efficiency fertilizers, phosphogypsum, water-retention polymer, coffee husk and organic compost, which can act as soil conditioners, modifying the soil conditions, in addition to chemical, physical and biological characteristics (Castro et al., 2014; Fernandes et al., 2013; Guelfi, 2017; Serafim et al., 2013), interfering with plant growth and, consequently, yield, as they interfere with soil-water-plant system relationships, as well as nutrient absorption, since water is a vehicle for its conduction to the plant.

Therefore, several technologies are available for coffee cultivation. Some old but not inefficient (and frequently ceased to be used by coffee growers), and some newer ones that have been incorporated into the production process (polyethylene 
film as a soil cover, water-retention polymer as a soil water storage, phosphogypsum, slow-release fertilizers, among others). The isolated effects of these different technologies are known, but there are no studies in the literature evaluating their simultaneous use.

The objective of this study was to evaluate the effects on soil chemical attributes in a coffee growing area, according to different agronomic techniques used and their associations.

\section{MATERIAL AND METHODS}

The experiment was conducted in the field, in an experimental area of the Coffee Sector, at the Department of Agriculture - DAG, of Universidade Federal de Lavras UFLA, in Lavras - MG, from January 2016 to October 2018. The geographical coordinates of the area are $21^{\circ} 13^{\prime} 36.47^{\prime \prime}$ South latitude and 44 $57^{\prime} 40.35$ West longitude, with an average altitude of 975 meters. According to the Koppen classification, the region climate is classified as Cwa, mesothermal with mild summers and winter droughts (Sá Júnior et al., 2012).

The soil of the experimental area was classified as Oxisol (Embrapa, 2013), of clay texture. The chemical characteristics (soil layer 0 to $0,2 \mathrm{~m}$ and 0,2-0,4 $\mathrm{m}$ ) and soil particle size before experiment implementation are presented in Table 1.

Coffee was planted in January 2016, with 'Mundo Novo IAC - 379-19' seedlings, with a spacing of $3.6 \mathrm{~m}$ between rows and $0.75 \mathrm{~m}$ between plants in the planting row. Soil correction and phosphate fertilization were performed according to the results of soil analysis (Table 1), following the recommendations of Guimarães et al. (1999).

The factors under study were arranged in a $3 \times 2 \times 5$ factorial scheme, making a total of 30 treatments allocated in the experimental area in subdivided plots. A randomized block design with three replications was used. In the plots, three soil managements were randomized (soil cover with polyethylene film, soil cover with brachiaria grass and conventional management of spontaneous vegetation). In the subplots, two types of fertilizers used in the fertilization of coffee trees were tested (conventional and increased-efficiency fertilizer). In the sub-subplots, four soil conditioners were tested (coffee husk, phosphogypsum, water retention polymer, organic compost), and the control without conditioner. Each experimental unit consisted of six plants; the four central plants were considered as useful and, for those between the treatment rows, a border line was used.

For soil management with polyethylene film cover, a $1.60 \mathrm{~m}$ wide double-sided (black and white) material was installed on the planting row, soon after the nursery coffee was transplanted to the field, with the white part facing up. For the application of fertilizers and soil conditioners on the plots that were covered with the polyethylene film, it was necessary to lift the film, which was placed in the original position after the application of the treatments.

For the implementation of ecological management with brachiaria grass, $10 \mathrm{~kg} \mathrm{ha}^{-1}$ of Urochloa decumbens was sown between coffee rows ( $1.00 \mathrm{~m}$ on each side of the planting row). The treatment consisted of mowing the grass between rows, with the aid of mechanical mowing and keeping the planting row always covered by the plant residues from the harvest, with the aid of a rake.

To quantify the brachiaria grass biomass placed on the soil in the planting row, samples were collected in each experimental unit. Subsequently, fresh weight was determined and it was found that, on average, $1.8 \mathrm{~kg} \mathrm{~m}^{-2}$ plant material of the poaceae were deposited after each harvest.

Table 1: Chemical analysis (depth $0-0,2 \mathrm{~m}$ and 0,2-0,4 $\mathrm{m}$ ) and soil particle size of the experimental area, before experiment implementation. Lavras - MG, 2015.

\begin{tabular}{|c|c|c|c|c|c|c|c|c|c|c|}
\hline Depth (m) & $\mathrm{pH}$ & $\mathrm{P}$ & $\mathrm{K}$ & $\mathrm{Ca}^{2+}$ & $\mathrm{Mg}^{2+}$ & $\mathrm{Al}^{3+}$ & $(\mathrm{H}+\mathrm{Al})$ & SB & $(\mathrm{t})$ & (T) \\
\hline $0-0,20$ & 5.0 & 4.5 & 104 & 1.5 & 0.5 & 0.2 & 3.5 & 2.3 & 2.5 & 5.7 \\
\hline \multirow[t]{2}{*}{$0,20-0,40$} & 4.6 & 1.4 & 48 & 0.5 & 0.2 & 0.5 & 4.4 & 0.8 & 1.3 & 5.1 \\
\hline & V & $\mathrm{m}$ & M.O. & P-Rem & $\mathrm{Zn}$ & $\mathrm{Fe}$ & $\mathrm{Mn}$ & $\mathrm{Cu}$ & $\mathrm{B}$ & $\mathrm{S}$ \\
\hline $0-0,20$ & 39.6 & 8.1 & 2.1 & 27.1 & 2.9 & 102.7 & 22.9 & 4.1 & 0.3 & 35.9 \\
\hline $0.20-0,40$ & 15.9 & 37.8 & 1.3 & 16.5 & 0.7 & 93.5 & 10.6 & 3.2 & 0.5 & 60.7 \\
\hline \multicolumn{2}{|c|}{ Soil classification } & \multicolumn{3}{|c|}{ Clay } & & $\begin{array}{c}\text { Silt } \\
\left(\text { dag kg }^{-1}\right)\end{array}$ & & \multicolumn{3}{|c|}{ Sand } \\
\hline \multicolumn{2}{|c|}{ Clay texture } & \multicolumn{3}{|c|}{44} & \multicolumn{3}{|c|}{9} & \multicolumn{3}{|c|}{47} \\
\hline
\end{tabular}

Source: The author (2019).

Report issued by the Chemical and Physical Soil Analysis Laboratory, Department of Soil Sciences of Universidade Federal de Lavras.

Note: $\mathrm{pH}\left(\mathrm{H}_{2} \mathrm{O}\right) ; \mathrm{P}$ and $\mathrm{K}\left(\mathrm{mg} \mathrm{dm}^{-3}\right) ; \mathrm{Ca}^{2+}, \mathrm{Mg}^{2+}, \mathrm{Al}^{3+}, \mathrm{H}^{+}+\mathrm{Al}^{3+}\left(\mathrm{cmol}_{\mathrm{c}} \mathrm{dm}^{-3}\right) ; \mathrm{SB}=$ exchangeable base sum $\left(\mathrm{cmol}_{\mathrm{c}} \mathrm{dm}^{-3}\right) ;(\mathrm{t})=\mathrm{effective}$ cation exchange capacity $\left(\mathrm{cmol}_{\mathrm{c}} \mathrm{dm}^{-3}\right) ;(\mathrm{T})=$ cation exchange capacity at $\mathrm{pH} 7.0\left(\mathrm{cmol}_{\mathrm{c}} \mathrm{dm}^{-3}\right) ; \mathrm{V}=$ base saturation index $(\%)$; m = aluminum saturation index (\%); M. O. $\left(\operatorname{dag~kg}{ }^{-1}\right)$; P-Rem $\left(\mathrm{mg} \mathrm{L}^{-1}\right)$; Zn, Fe, Mn, Cu, B, S $\left(\mathrm{mg} \mathrm{dm}^{-3}\right)$. 
Conventional soil management with spontaneous vegetation was carried out by using a mechanical mower between rows, keeping a $1.00 \mathrm{~m}$ strip on each side of the always clean planting row, through weeding and application of post and pre-emergent herbicides. For the subplot treatment, two different technologies were used to supply nitrogen $(\mathrm{N})$ and potassium $(\mathrm{K})$ to plants. The conventional fertilizer used was NPK $20-00-20$ plus conventional urea $(45 \% \mathrm{~N})$ when necessary (Guimarães et al., 1999). The increased-efficiency fertilizer used was a commercial product $(37 \% \mathrm{~N})$, with elemental sulfur-coated urea plus a layer of organic polymers associated with another commercial product $\left(52 \% \mathrm{~K}_{2} \mathrm{O}\right)$ with potassium chloride, also coated with elemental sulfur plus one layer of organic polymers, following the same dose of $\mathrm{N}$ and $\mathrm{K}$ established by the recommendation of Guimarães et al. (1999).

The products used as soil conditioners were coffee husk, phosphogypsum, water-retention polymer and organic compost. Coffee husk, phosphogypsum and organic compost were applied to the soil in the coffee canopy projection soon after planting (Guimarães et al., 1999).

In the treatments with phosphogypsum $(18 \%$ calcium and $15 \%$ sulfur), $300 \mathrm{~g} \mathrm{~m}^{-2}$ were applied, based on the recommendation of Guimarães et al. (1999), from the results of soil analysis (texture), at a depth of 0.20 to $0.40 \mathrm{~m}$ (Table 1).

The treatment containing the water-retention polymer as a soil conditioner was applied at the time of planting, at a dose of $1.5 \mathrm{~L}$ of the prepared solution, in each planting hole (Pieve et al., 2013).

The subplot named control did not receive soil conditioner, being influenced only by the factors management (cover between rows with brachiaria grass or polyethylene film and traditional management with uncovered planting row) and type of fertilizer (traditional and increased-efficiency). All products used as conditioners were reapplied annually, always in October.

This study aimed to evaluate soil chemical attributes in coffee growing with different agronomic techniques through the evaluation of soil $\mathrm{pH}$, phosphorus $(\mathrm{P})$, potassium $(\mathrm{K})$, calcium $(\mathrm{Ca})$, magnesium $(\mathrm{Mg})$, aluminum saturation $(\mathrm{m})$ and base saturation (V\%), by soil analysis carried out in October 2018 (Soil Analysis Laboratory of Universidade Federal de Lavras - UFLA) and leaf analysis in December 2018 (Leaf Analysis Laboratory from REHAGRO research). It is noteworthy that the chemical attributes of the leaf were used only for principal component analysis through multivariate analysis.

After obtaining the data, the normality of the errors was verified through by the Shapiro-Wilk test. Subsequently, the analysis of variance was performed with the significance of the variation sources verified by the $\mathrm{F}$ test, at $5 \%$ probability. For the study of the means, when significance was verified, the comparison was made by overlapping the standard error of the mean, to study the effects of interactions and the effects of the main factors. These statistical procedures and multivariate data analysis were performed using the $\mathrm{R}$ software ( $\mathrm{R}$ Core Team, 2017). Canonical variable analysis was performed to evaluate the similarity of treatments through graphic dispersion (Friendly; Fox, 2017).

\section{RESULTS AND DISCUSSION}

The results presented refer to the characteristics that showed significant differences in the analysis of variance.

For soil hydrogen potential $(\mathrm{pH})$ in coffee trees, the fertilizer had a significant effect $(\mathrm{p}<0.05)$, in interaction with soil cover management, as well as interaction with conditioners.

For the interaction of soil cover management and fertilizer, there are no significant differences in $\mathrm{pH}$ between the types of fertilizer within each soil management used. However, when using conventional fertilizer, the soil with the presence of polyethylene film is more acidic than associations: spontaneous vegetation + conventional fertilizers or increased efficiency fertilizers, and brachiaria grass + conventional fertilizers (Figure 1).

For the interaction of conditioners and fertilizers, there was a difference in the treatments in which conventional fertilizer was used, with higher $\mathrm{pH}$ values were observed with the use of organic compost, followed by coffee husk when compared to the other soil conditioners (Figure 2).

In the specific case of increased-efficiency fertilizer, the use of organic compost resulted in higher $\mathrm{pH}$ values when compared to the water-retention polymer and the control (Figure 2).

For the characteristic phosphorus content $(\mathrm{P})$, soil cover management had a significant effect $(\mathrm{p}<0.05)$ in interaction with the conditioners.

For the interaction of the factors soil cover management and conditioners, there was a difference between soil $\mathrm{P}$ so that, for the management using brachiaria grass and conventional management of spontaneous vegetation, the treatments with organic compost used as conditioners showed higher contents of this nutrient in the soil, when compared to the soil of the other soil conditioners. In the management with polyethylene film, there was no difference between soil $\mathrm{P}$ contents in relation to the different conditioners (Figure 3).

Thus, the phosphorus content in the soil was higher when the organic compost was used as a conditioner, especially in the soil where there was some kind of vegetation as a cover. For the characteristic potassium $(\mathrm{K})$ content in the soil, soil cover management had a significant effect $(\mathrm{p}<0.05)$ in interaction with the conditioners. 


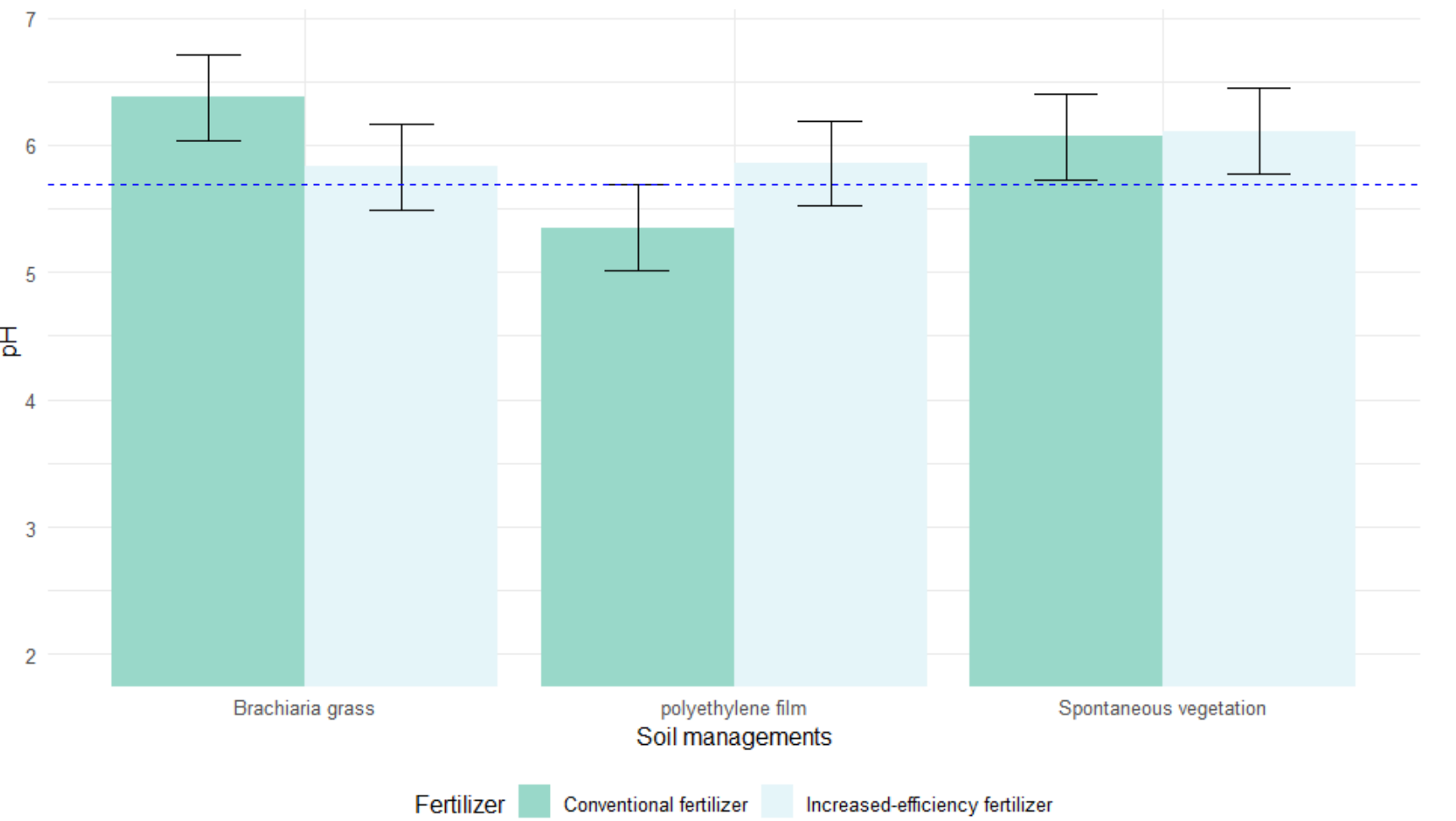

Figure 1: Soil pH value using three types of soil cover management (Brachiaria grass, polyethylene film and conventional spontaneous vegetation management) and two types of fertilizers (conventional and increased efficiency).

Caption: Bars represent mean \pm standard error.

Source: The author (2019).

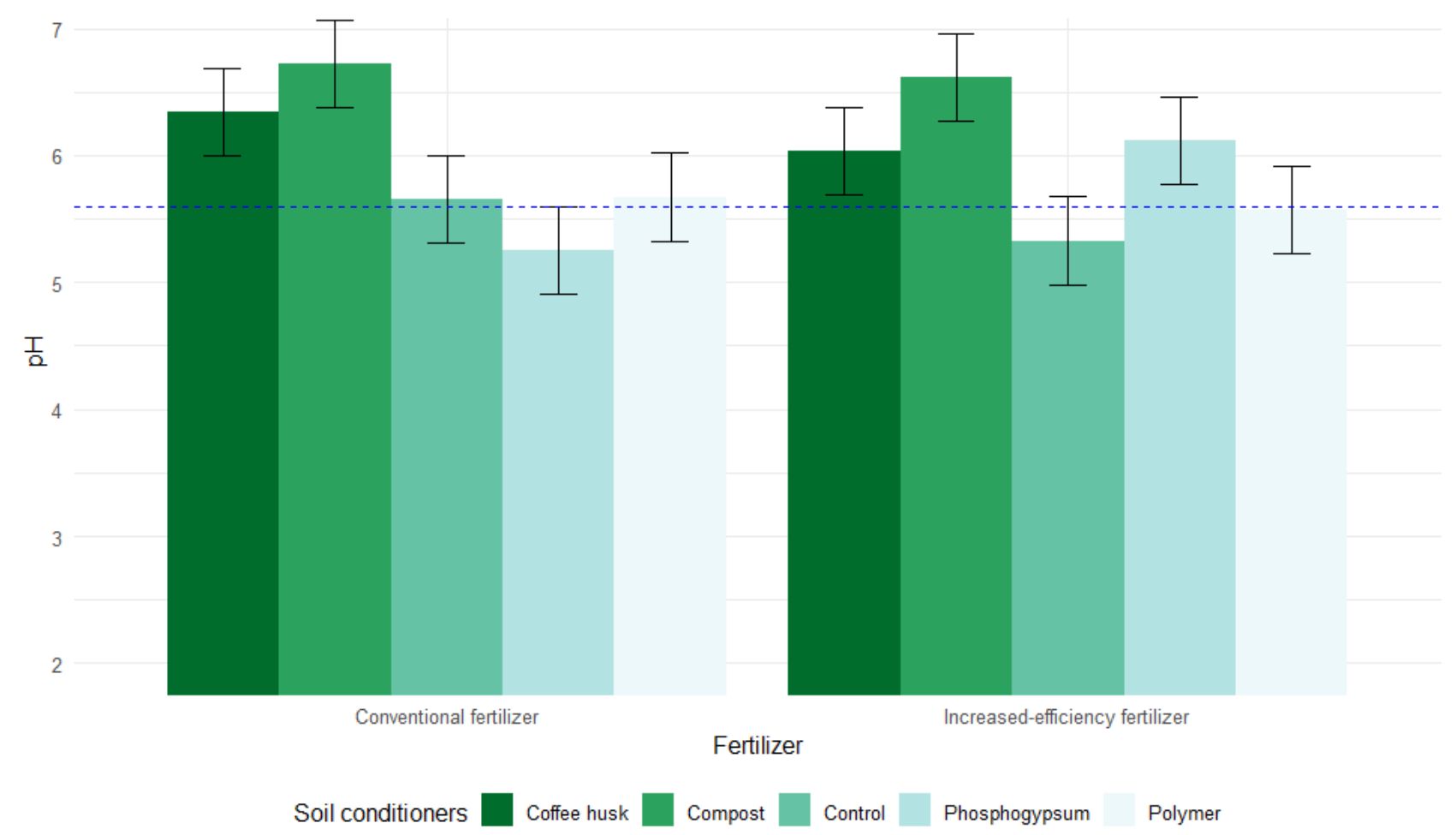

Figure 2: Soil pH using two types of fertilizers (conventional and increased efficiency) and five soil conditioners (coffee husk, organic compost, phosphogypsum, water-retention polymer and control - without the use of conditioners).

Caption: Bars represent mean \pm standard error.

Source: The author (2019). 


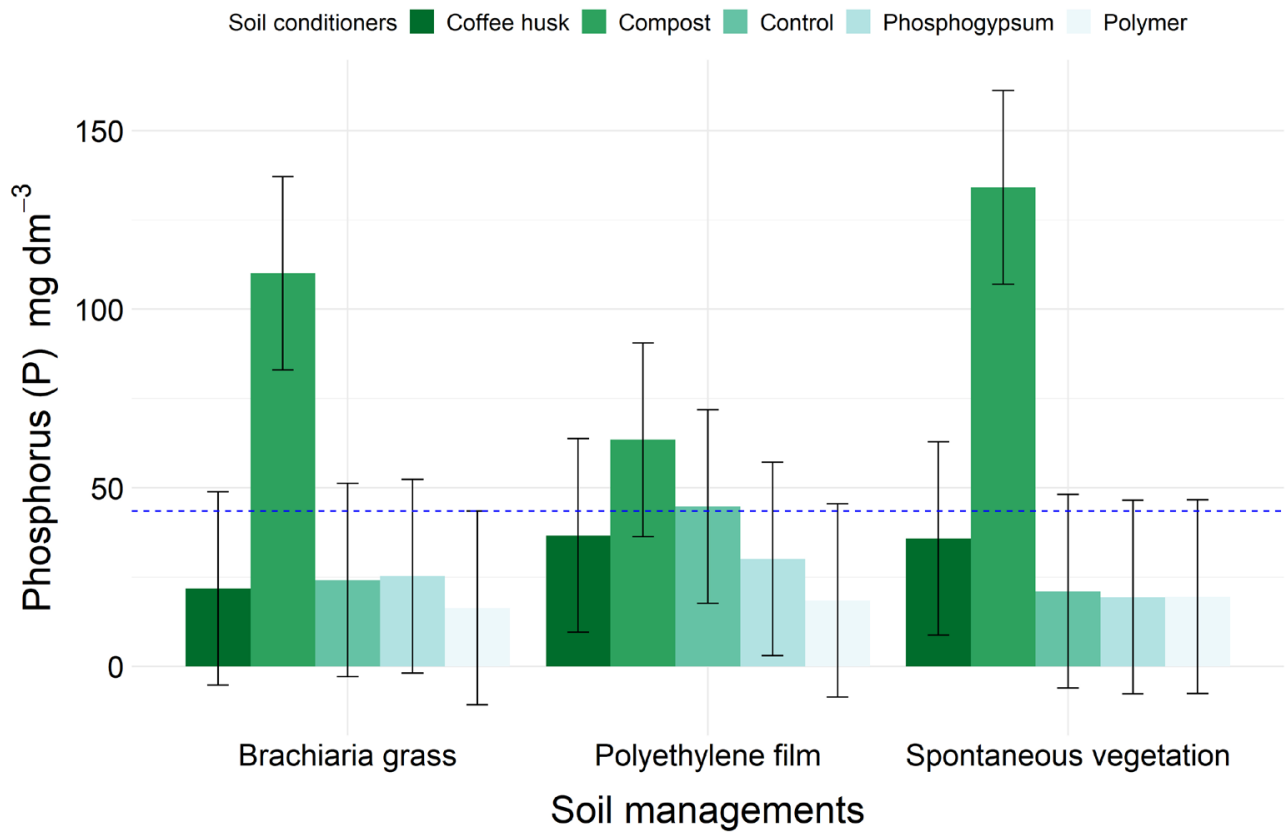

Figure 3: Phosphorus $(P)$ content in the soil in under three types of soil cover management (Brachiaria grass, polyethylene film and conventional spontaneous vegetation management) and five soil conditioners (coffee husk, organic compost, phosphogypsum, water-retention polymer and control - without conditioners).

Caption: Bars represent mean \pm standard error.

Source: The author (2019).

There was a difference between soil $\mathrm{K}$ content so that, in the three proposed managements, the use of coffee husk provideda higher content of this nutrient, when compared to the other conditioners. In general, in soils with the use of the organic compost, the potassium content is lower than in the soil with the use of coffee husk, but higher than the other conditioners (Figure 4).

The calcium $(\mathrm{Ca})$ content in the soil varied significantly $(p<0.05)$, when the effects of fertilizers used (conventional and increased efficiency) were combined with the different products used as conditioners. With both conventional and increased-efficiency fertilizers, the calcium content was higher in the plots that received the organic compost, except for the plots that received phosphogypsum combined with increasedefficiency fertilizers, which also had high calcium contents, compared to the other treatments (Figure 5).

The magnesium $(\mathrm{Mg})$ content in the soil cultivated with coffee had significant effect $(p<0.05)$, when the use of conventional and increased-efficiency fertilizers were combined with the different products used as conditioners.

There was a difference between the Mg content in the soil with higher levels in the treatments using conventional fertilizer, associated with the organic compost or the absence of conditioners (control), in relation to the other treatments with other conditioners. On the other hand, in the soils of plots that received increased-efficiency fertilizers, there were no differences in magnesium contents in any of the associations with the different conditioners (Figure 6).

Evaluating the percentage of base saturation $(\mathrm{V} \%)$ in the soil, there was a significant difference $(p<0.05)$ when the use of conventional and increased-efficiency fertilizers was combined in interaction with the use of different products as soil conditioners.

In the soils of plots that received the conventional fertilizer, the use of organic compost implied a higher percentage of base saturation ( $\mathrm{V} \%$ ), when compared to the soils that received the conditioners phosphogypsum, waterretention polymer and the control (without conditioners). On the other hand, in soils that received increasedefficiency fertilizers, the use of organic compost, coffee husk and phosphogypsum resulted in soils with higher base saturation, when compared to the soil that received the water-retention polymer without conditioners (control) (Figure 7).

Evaluating the aluminum saturation $(\mathrm{m})$ in the coffeecultivated soil, a significant effect $(p<0.05)$ was observed between the soils of plots that received the different soil conditioners, regardless of the fertilizer used (conventional or increased efficiency), or the management used in the soil cover. 
Soil conditioners $\square$ Coffee husk $\square$ Compost $\square$ Control $\square$ Phosphogypsum Polymer

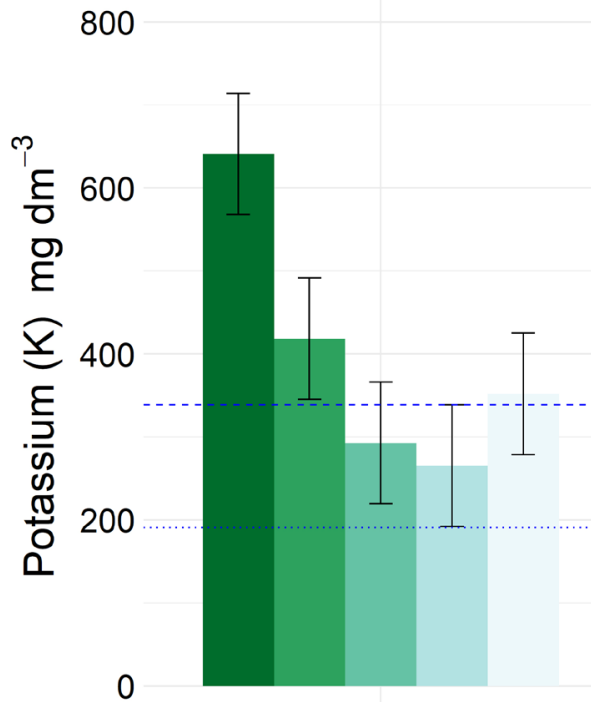

Brachiaria grass

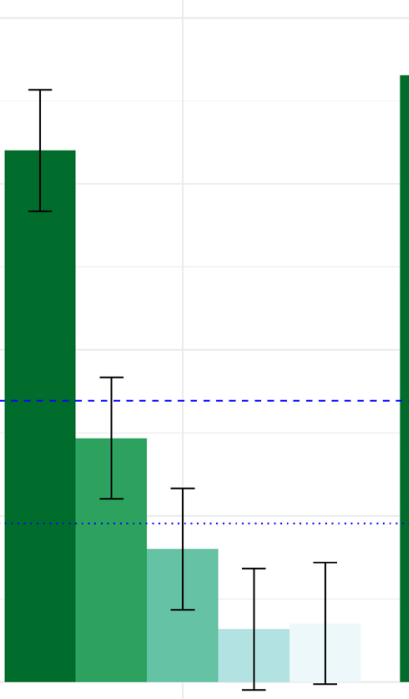

Polyethylene film

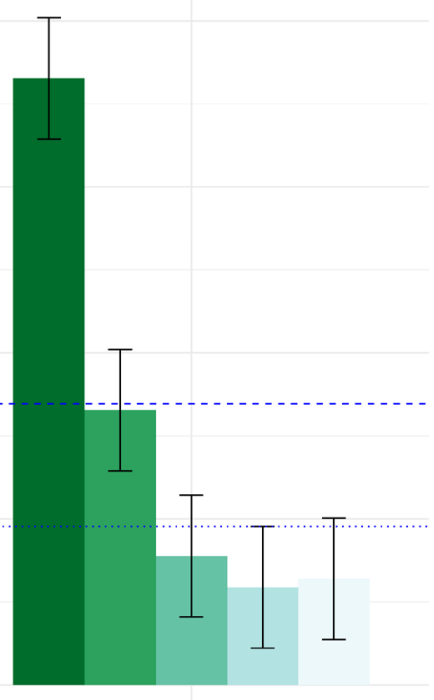

Spontaneous vegetation

Soil managements

Figure 4: Potassium (K) content in the soil in coffee trees grown under three types of soil cover management (Brachiaria grass, polyethylene film and conventional spontaneous vegetation management) and five soil conditioners (coffee husk, organic compost, phosphogypsum, water-retention polymer and control - without conditioners).

Caption: Bars represent mean \pm standard error.

Source: The author (2019).

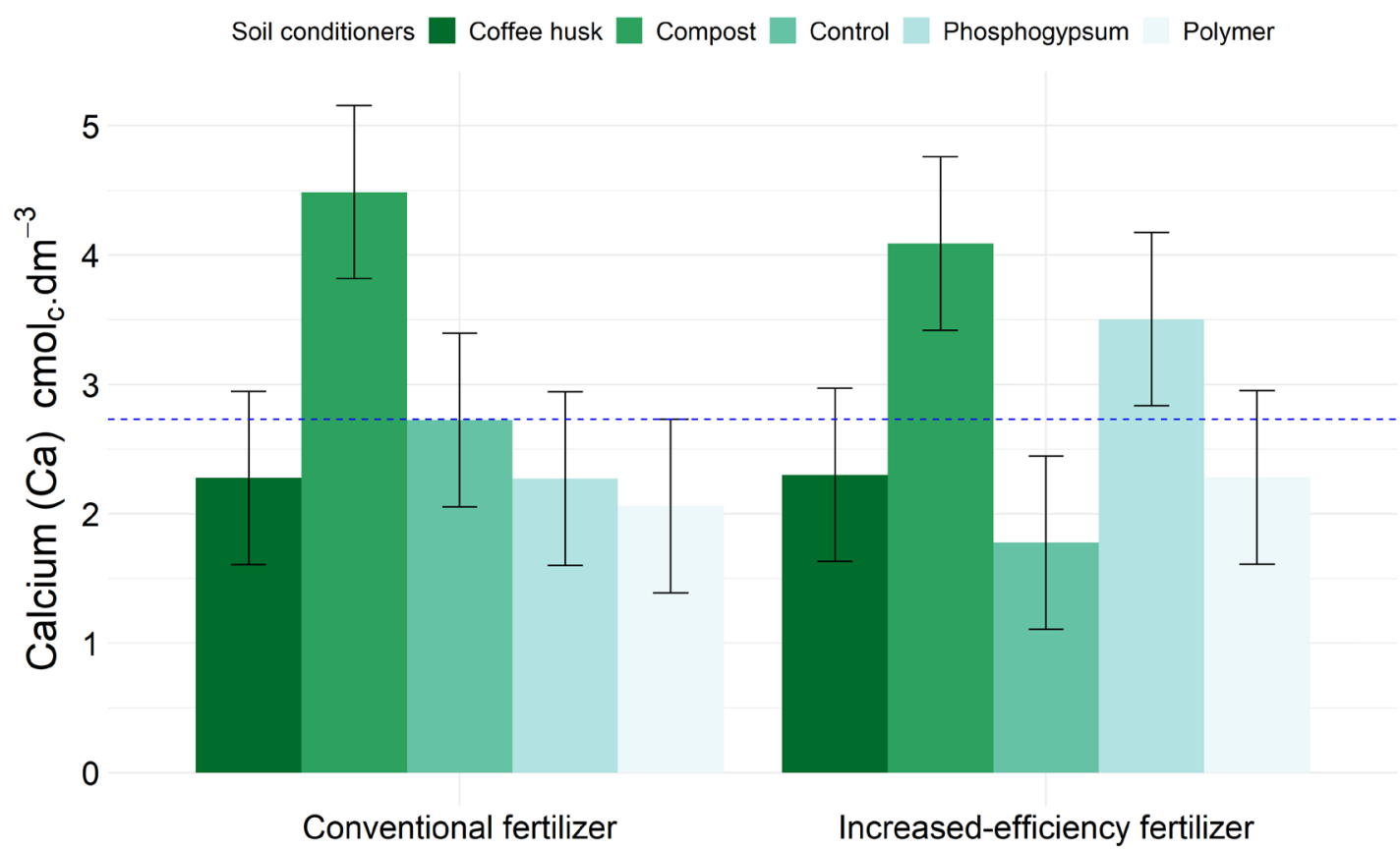

Fertilizer

Figure 5: Calcium (Ca) content in the soil grown with coffee trees, with the addition of two types of fertilizers (conventional and increased efficiency) and five soil conditioners (coffee husk, organic compost, phosphogypsum, water-retention polymer and control - without conditioners).

Caption: Bars represent mean \pm standard error.

Source: The author (2019). 


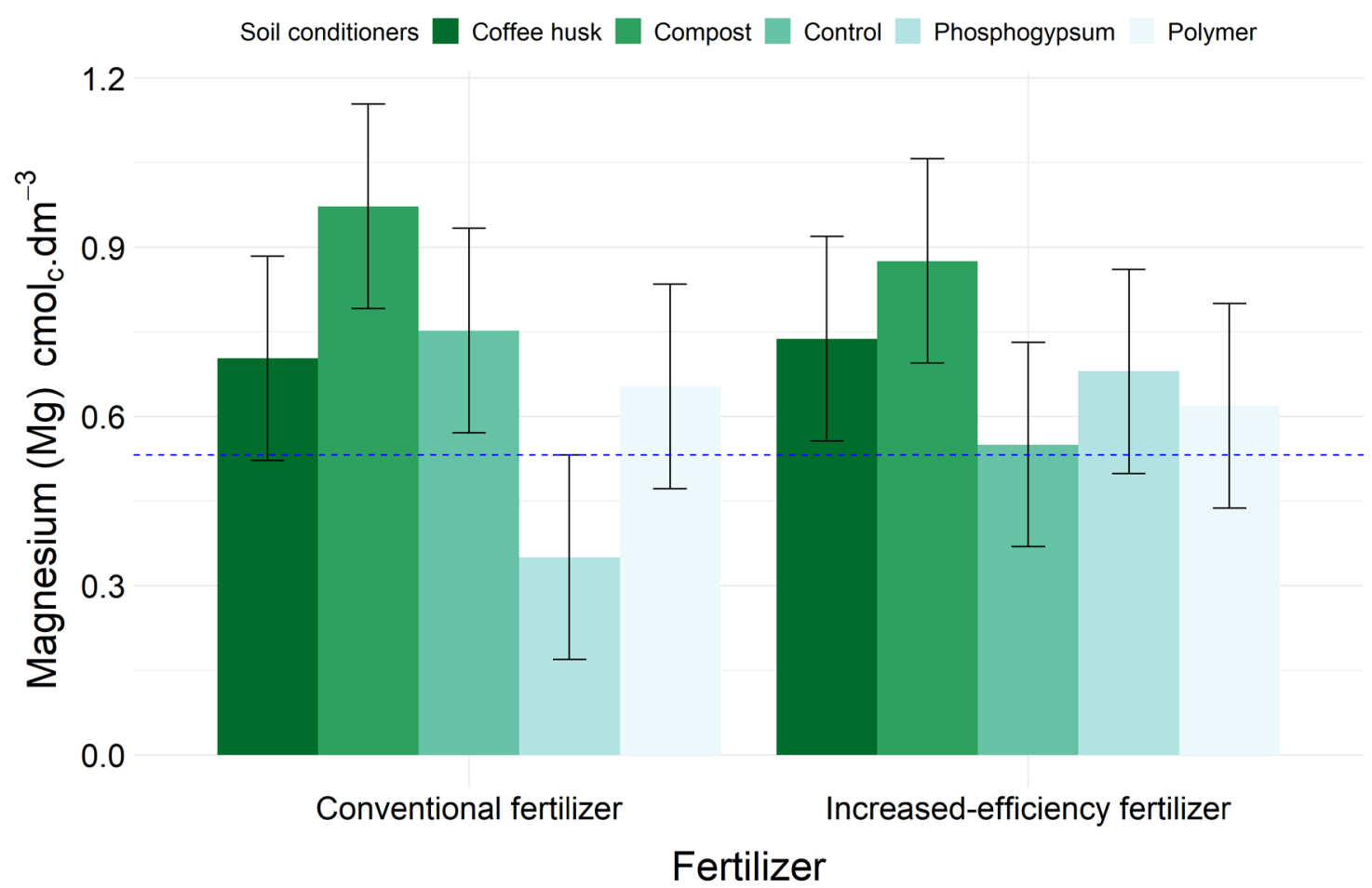

Figure 6: Magnesium (Mg) content in the soil grown with coffee trees, with the addition of two types of fertilizers (conventional and increased efficiency) and five soil conditioners (coffee husk, organic compost, phosphogypsum, water-retention polymer and control - without conditioners).

Caption: Bars represent mean \pm standard error. Source: The author (2019).

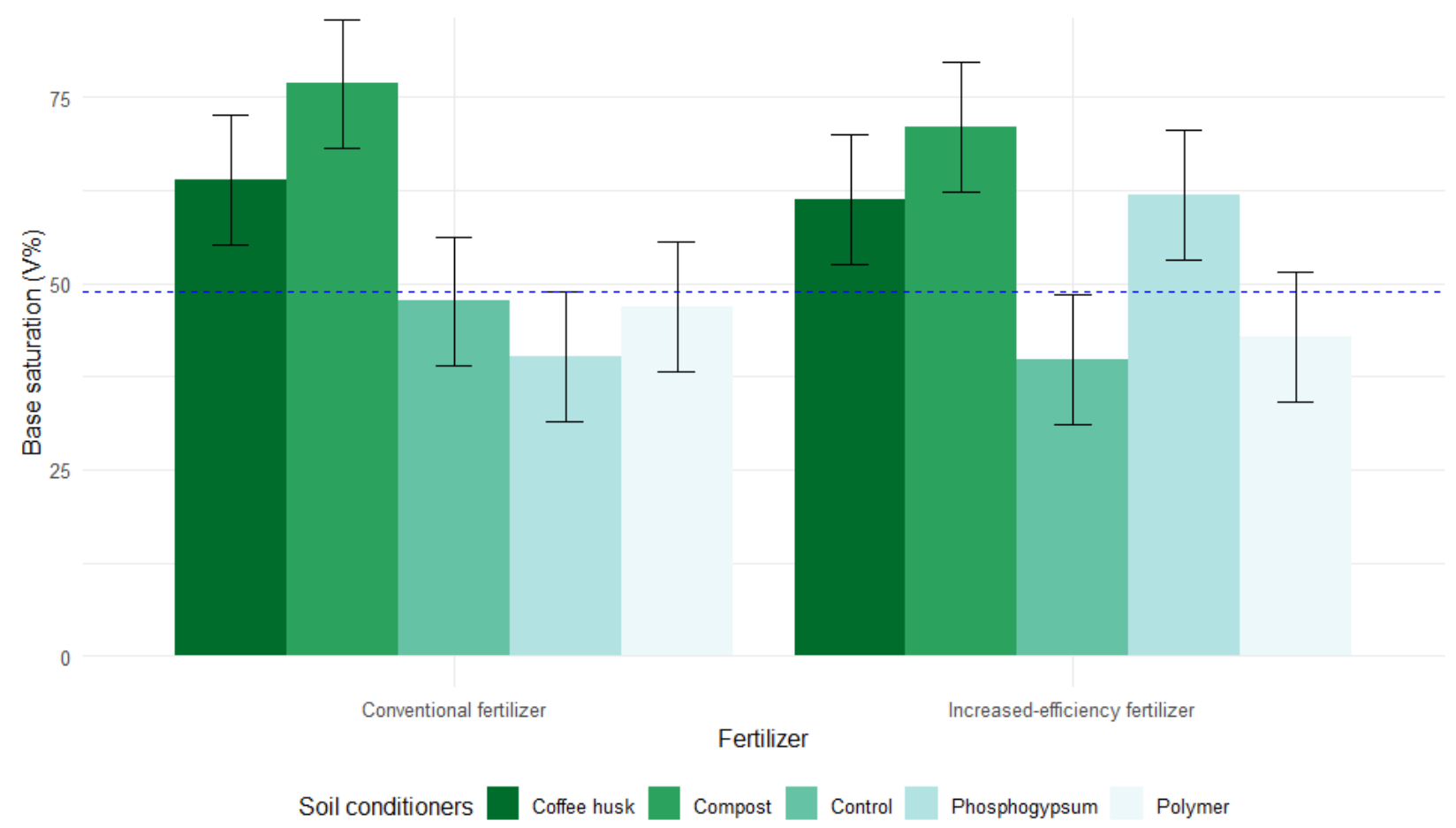

Figure 7: Base saturation ( $\mathrm{V} \%$ ) in the soil, in coffee crops with two types of fertilizers (conventional and increased efficiency) and five soil conditioners (coffee husk, organic compost, phosphogypsum, water-retention polymer and control - without conditioners). Caption: Bars represent mean \pm standard error.

Source: The author (2019). 
Thus, the use of organic compost yielded lower aluminum saturation in the soils of plots that received coffee husk, organic compost and phosphogypsum, when compared to the soils of plots that received the water-retention polymer or that did not receive conditioners (control) (Figure 8).

The dispersion graph (Figure 9) shows the grouping of the thirty treatments resulting from the combination of the three types of soil cover management, the two types of fertilizers and the five conditioners (four plus the control), resulting from the canonical analysis in the different evaluation periods.

The treatments with the coffee husk were grouped in the lower right quadrant, regardless of the fertilizer or cover management adopted and these treatments were very close to the characteristics of potassium in the soil, and potassium and phosphorus in the leaf. However, these treatments were far from leaf magnesium (Figure 9).

However, in the upper right quadrant, it was found that the treatments with the presence of organic compost were grouped, independently of the fertilizer or cover management used and that they were very close to the characteristics of $\mathrm{Ca}, \mathrm{P}$ and $\mathrm{Mg}$ contents, besides $\mathrm{V}(\%)$ and cation exchange capacity (T). However, they were opposed to aluminum saturation (Figure 9).

In this study, it was found that, after conducting the experiment for three consecutive years, applying the study factors, the chemical characteristics of the soil underwent major changes.

Soil $\mathrm{pH}$ was influenced by the type of conditioner used and, when fertilization with conventional fertilizer was used, higher $\mathrm{pH}$ values were observed with the use of organic compost and coffee husk. In the case of fertilization with increasedefficiency fertilizers, the highest $\mathrm{pH}$ values were observed with the combined use with the organic compost, followed by the combination with coffee husk and phosphogypsum.

Soil management with the use of covers, as a conventional management of spontaneous vegetation and with brachiaria grass, also yielded higher soil $\mathrm{pH}$, when compared to the soils of plots that received the management with the polyethylene film as a cover, when using conventional fertilization.

The increase in $\mathrm{pH}$ in the soils of plots that associated the soil conditioners with the covers can be explained by the greater organic matter supply to the system, increasing the buffering effect and, consequently, being less subject to $\mathrm{pH}$ fluctuation (Pereira; Anjos; Valladares, 2005).

Centeno et al. (2017) report that soils with lower buffering power are more subject to $\mathrm{pH}$ variation, and thus the application of small amounts of corrective or fertilizer may lead to marked differences in $\mathrm{pH}$ values. Thus, in the present work, it was found that organic conditioners increased

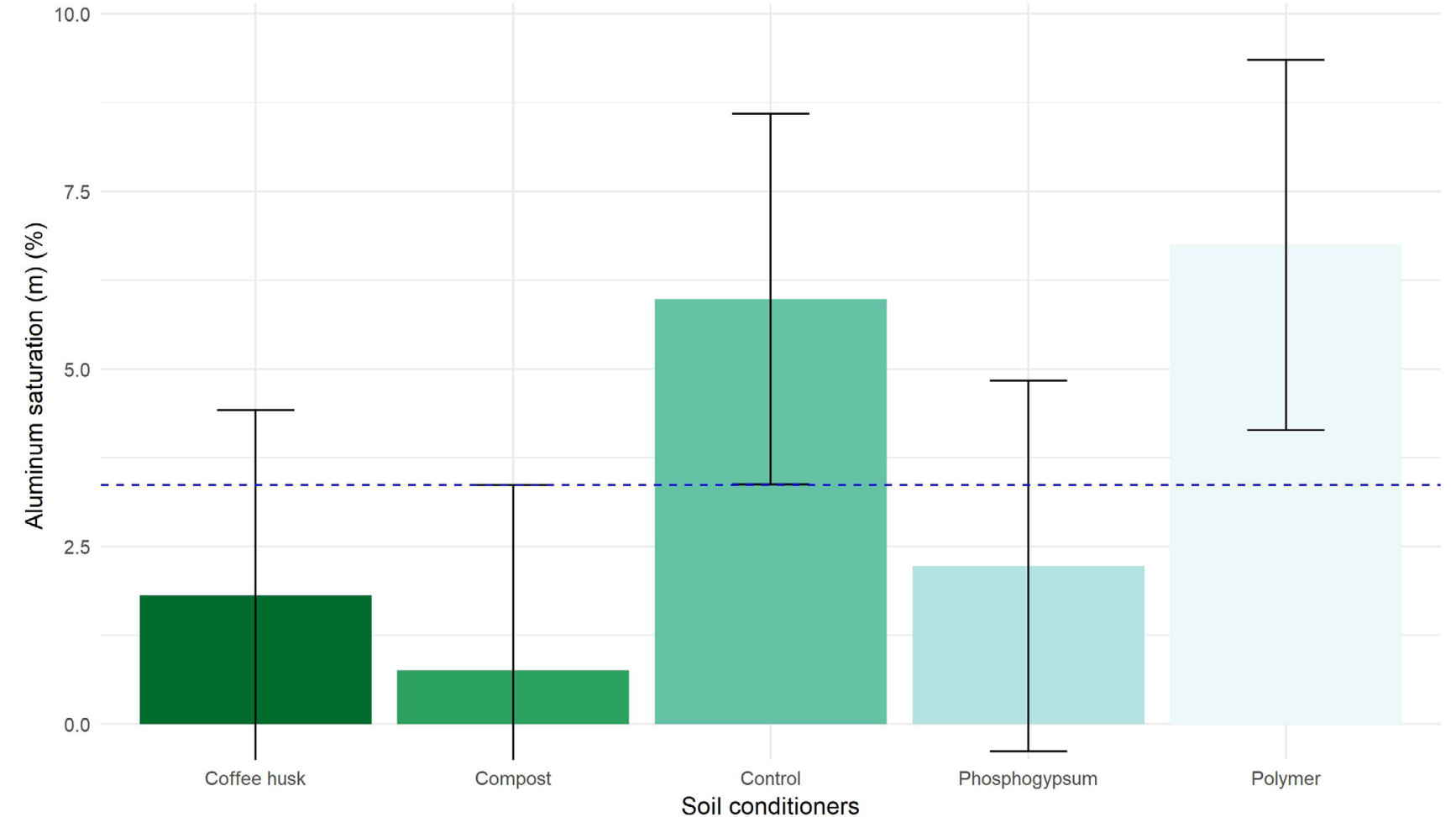

Figure 8: Aluminum saturation $(\mathrm{m})$ in the soil grown with coffee trees, with four soil conditioners (coffee husk, organic compost, phosphogypsum, water-retention polymer) and the control (without conditioners).

Caption: Bars represent mean \pm standard error.

Source: The author (2019). 
the power of the soil buffer. Allied to this, due to the large quantities of fertilizers used to supply the demand of the plants, there was a consequent reduction in the $\mathrm{pH}$ values, due to their dissociation reactions in the soil. Therefore, where the buffering power was higher, the $\mathrm{pH}$ was not greatly influenced, so that treatments without the use of organic conditioners had more acidic soil.

The phosphorus content found in the soil increased in relation to the other treatments, as a function of the application of the organic compost, possibly due to the high contents of $\mathrm{P}$ in the organic compost. Another possible explanation for the high phosphorus content in the plots that received organic compost is that, under abundant organic matter, phosphate fertilization is optimized and this nutrient is less subject to fixation in the soil, since organic acids compete for $\mathrm{P}$ adsorption sites (Rampim et al., 2013).

It is also noteworthy that the great capacity for exchanging cations inherent in the organic matter of the compound, which consequently has a large amount of negative charges, repels phosphorus, thus making it more available to plants (Condé et al., 2013).

Potassium (K) content in the soil was influenced mainly by the addition of coffee husk, so that the plots that received

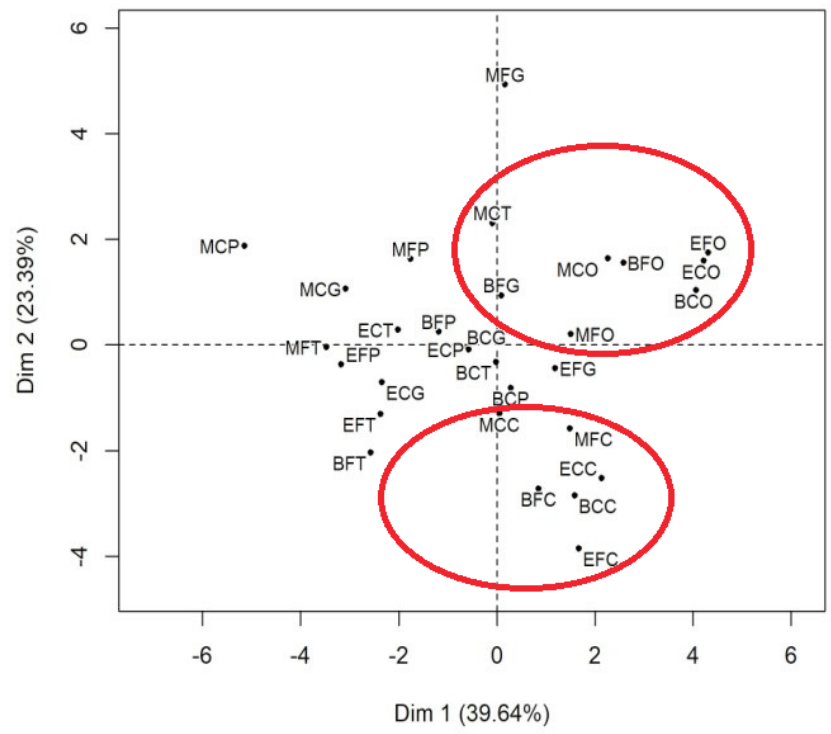

this conditioner presented higher $\mathrm{K}$ content in the soil, when compared to the others. Several studies report an increase in soil $\mathrm{K}$ content due to the use of coffee husk, since potassium levels in this soil conditioner are high, ranging from 2-4\% (Carvalho et al., 2012; Guimaraes et al., 1999).

Regarding the nutrients calcium $(\mathrm{Ca})$ and magnesium $(\mathrm{Mg})$, the contents found in the soil were significantly influenced by organic compost and phosphogypsum use. Both organic compost and phosphogypsum act by supplying calcium directly to the soil, and the organic compost still provides magnesium (Guimarães et al., 1999). Cardoso et al. (2011) observed a linear increase in soil $\mathrm{Ca}$ and $\mathrm{Mg}$ contents by the application of organic compounds in lettuce cultivation. Similarly, Almeida (1991), working with the okra crop, verified increases in $\mathrm{Ca}$ and $\mathrm{Mg}$ contents, due to the use of organic compost. It is noteworthy that the various organic sources used in composting and the final product have variable composition (Kiehl, 2001) and it is difficult to characterize the organic fertilizers regarding their chemical composition and agronomic efficiency, since their diversity is great in relation to origin, degree of humidity and percentage of conversion (Guimarães et al., 1999).

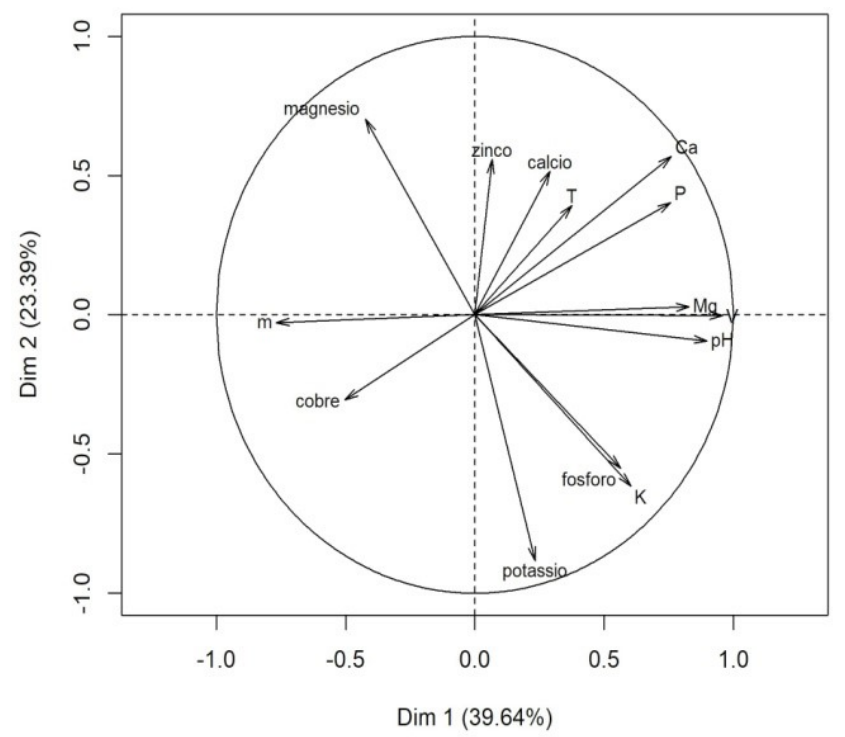

Figure 9: Graphic dispersion of coffee trees grown with different treatments obtained from the combination of three types of soil cover management (Brachiaria grass, polyethylene film and conventional spontaneous vegetation management), two types of fertilizers (conventional and increased efficiency) and five soil conditioners (coffee husk, organic compost, phosphogypsum, water-retention polymer and control) (9.1), in relation to the first (canonical variable 1) and the second (canonical variable 2), based on soil and leaf nutritional characteristics (9.2).

Caption: In the initial letters, M (polyethylene film), B (Brachiaria grass) and E (Spontaneous vegetation). For the other letters, follow description below:

CC (Conventional fertilizer/ Coffee husk), CG (Conventional fertilizer/ Phosphogypsum) CP (Conventional fertilizer/ Polymer) CO (Conventional fertilizer/ Compost) CT (Conventional fertilizer/ Control).

FC (Increased-efficiency fertilizer/ Coffee husk), FG (Increased-efficiency fertilizer/ Phosphogypsum) FP (Increased-efficiency fertilizer/ Polymer) FO (Increased-efficiency fertilizer/ Compost) FT (Increased-efficiency fertilizer/ Control).

Source: The author (2019). 
Also, for the characteristic of soil base saturation percentage (V\%), the organic compost and coffee husk influenced directly, increasing $\mathrm{V} \%$ in values higher than those provided by the other soil conditioners. As base saturation is related to soil $\mathrm{Ca}, \mathrm{Mg}, \mathrm{K}$ contents, this behavior of the conditioners, which stood out in this characteristic, occurs by increasing the content of these nutrients. In soil grown with lettuce, with the addition of organic compost at increasing linear doses, an increase in soil base saturation was also observed due to the use of organic compost (Cardoso et al., 2011).

Regarding the characteristic aluminum saturation, the conditioners organic compost, coffee husk and phosphogypsum implied its reduction in the soil. Almeida (1991) also found a reduction in aluminum saturation through the use of soil conditioner. The same author also comments that the organic compost acted reducing $\mathrm{Al}^{+3}$ content in the soil and its ready availability to the plants.

Also, it should be noted that, as previously exposed, the negative charges inherent to the organic fraction of these conditioners, such as carboxylic radicals, act, even if temporarily, by adsorbing the exchangeable aluminum from the soil. Thus, this element, which is toxic to plants, is unavailable for their absorption (Briedis et al., 2012).

Through principal component analysis (multivariate), it was found that the treatments, in the presence of coffee bark, grouped and were close to the potassium content in the soil and leaves and phosphorus in the leaves, but opposed to leaf magnesium. This can be explained by the absorption site competition between potassium and magnesium, so that excess potassium, especially through the use of coffee husk, prevents the absorption of magnesium, which is unavailable to the plant by the interionic competitive inhibition effect (Malavolta, 1980). Studies on garlic (Büll et al., 2001) and pumpkin (Sampaio Araújo et al., 2012) also report similar behavior, where excess potassium inhibits magnesium absorption by plants.

The grouping of treatments was also verified, as a result of the application of the organic compost, in which the contents of calcium, phosphorus, magnesium, $\mathrm{pH}$, cation exchange capacity (T) and base saturation were close, but opposed to aluminum saturation, showing the importance of organic compost in coffee crop management.

\section{CONCLUSIONS}

The use of fertilization (with conventional fertilizers or those with increased efficiency), combined with the application of organic compost or coffee husk, provide increased soil $\mathrm{pH}$, as well as the use of ecological management of brachiaria grass.

The use of organic compost as a soil conditioner increases phosphorus availability in the soil.

Coffee husk, as a soil conditioner, is an efficient potassium source for the coffee crop.
The use of organic compost and phosphogypsum increases the calcium and magnesium contents in the soil.

The use of organic compost and coffee husk was efficient in increasing the percentage of soil base saturation (V\%) grown with coffee.

The use of organic compost, coffee husk and phosphogypsum reduced aluminum saturation in the soil.

Treatments associated with the use of organic compost improve calcium, phosphorus and magnesium levels, increase $\mathrm{pH}$, cation exchange capacity $(\mathrm{T})$ and base saturation, besides decreasing aluminum saturation.

\section{REFERENCES}

ALMEIDA, D. L. de. Contribuição da adubação orgânica para a fertilidade do solo. Itaguai: UFRRJ, 1991. 192p.

BRIEDIS, C. et al. Soil carbon and fertility attributes in response to surface liming under no-tillage. Pesquisa Agropecuária Brasileira, 47(7):1007-1014, 2012.

BÜLL, L. T. et al. Fertilização potássica na cultura do alho vernalizado. Scientia Agricola, 58(1):157-163, 2001.

CARDOSO, A. I. I. et al. Alterações em propriedades do solo adubado com composto orgânico e efeito na qualidade das sementes de alface. Horticultura Brasileira, 29(4):594$599,2011$.

CARVALHO, M. et al. Compostos orgânicos no plantio do cupuaçuzeiro e do açaizeiro na Amazônia. Revista de Ciências Agro-Ambientais, 10(1):1-8, 2012.

CASTRO, A. M. C. et al. Initial growth of coffee tree with use of hidroretentor polymer and different intervals of watering. Coffee Science, 9(4):465-471, 2014.

CENTENO, L. N. et al. Textura do solo: Conceitos e aplicações em solos arenosos. Revista Brasileira de Engenharia e Sustentabilidade, 4(1):31-37, 2017.

CONDÉ, M. S. et al. Impact of fertirrigation with swine wastewater in an oxisol. Vértices, 15(2):161-178, 2013.

EMPRESA BRASILEIRA DE PESQUISA AGROPECUÁRIA - EMBRAPA. Sistema brasileiro de classificação de solos. 3. ed. Brasília, DF: 2013. 353p.

FERNANDES, A. L. T. et al. Redução da adubação mineral do cafeeiro arábica com a utilização de palhas de café. Coffee Science, 8(3):324-336, 2013.

FRIENDLY, M.; FOX, J. Candisc: Visualizing generalized canonical discriminant and canonical correlation analysis. Available in: <https://CRAN.R-project.org/ package $=$ candisc $>$. Access in: August, 15, 2017. 
GUELFI, D. R. S. Fertilizantes nitrogenados estabilizados, de liberação lenta ou controlada. Informações Agronômicas, 157:1-14, 2017.

GUIMARÃES, P. T. G. et al. Cafeeiro. In: RIBEIRO, A. C.; GUIMARÃES, P. T. G.; ALVARES, V. H. (Ed.). Recomendação para o uso de corretivos e fertilizantes em Minas Gerais: $5^{\text {a }}$ aproximação. Viçosa, MG: Ed. UFV, 1999. p. 289-302.

\section{INTERNATIONAL COFFEE ORGANIZATION - ICO. A} história do café. London, 2017. Available in: $<$ http:// www.ico.org/pt/coffee_storyp.asp?section=Sobre_o_ café>. Access in: 28 dez. 2018.

KIEHL, J. C. Produção de composto orgânico e vermicomposto. Informe Agropecuário, 229(212):40-52, 2001 .

MALAVOLTA, E. Elementos de nutrição mineral de plantas. São Paulo: Agronômica Ceres, 1980. 251p.

OLIVEIRA, C. M. et al. Economic impact of exotic insect pests in Brazilian agriculture. Journal of Applied Entomology, 137(1-2):1-15, 2013.

PEREIRA, M. G.; ANJOS, L. H. C.; VALLADARES, G. S. Organossolos: ocorrência, gênese, classificação, alterações pelo uso agrícola e manejo. In: VIDALTORRADO, P. et al. (Org.). Tópicos em ciência do solo. 4. ed. Viçosa, MG: SBCS, 2005. v. 4, p. 233-276.

PIEVE, L. M. et al. Uso de polímero hidro retentor na implantação de lavouras cafeeiras. Coffee Science, 8(3):314-323, 2013.
R Core Team. R: A language and environment for statistical computing [Computer software]. Vienna, Austria: R Foundation for Statistical Computing. 2017. Available in: $<$ https://www.R-project.org/>. Access in: February, 20, 2019.

RAGASSI, C. F.; PEDROSA, A. W.; FAVARIN, J. J. Aspectos positivos e riscos no consórcio cafeeiro e braquiária. Visão Agrícola, 8(12):29-32, 2013.

RAMPIM, L. et al. Fósforo e enxofre disponível, alumínio trocável e fósforo remanescente em latossolo vermelho submetido ao gesso cultivado com trigo e soja. Semina: Ciências Agrárias, 34(4):1623-1638, 2013.

ROCHA, O. C. et al. Qualidade físico-hídrica de um latossolo sob irrigação e braquiária em lavoura de café no cerrado. Coffee Science, 9(4):516-526, 2014.

SÁ JÚNIOR, A. de et al. Application of the Koppen classification for climatic zoning in the state of Minas Gerais, Brazil. Theoretical and Applied Climatology, 108(1/2):1-7, 2012.

SAMPAIO ARAÚJO, H. et al. Doses de potássio em cobertura na cultura da abóbora. Pesquisa Agropecuária Tropical, 42(4):469-475, 2012.

SERAFIM, M. E. et al. Qualidade física e intervalo hídrico ótimo em latossolo e cambissolo, cultivados com cafeeiro, sob manejo conservacionista do solo. Revista Brasileira de Ciência do Solo, 37(3):733-742, 2013.

YURI, J. E. et al. Cultivo de morangueiro sob diferentes tipos de mulching. Horticultura Brasileira, 30:424-427, 2012. 